\title{
POLITYKA PODATKOWA A KONKURENCYJNOŚĆ GOSPODARKI POLSKI, CZECH, SŁOWACJI I WEGIER W LATACH 2000-2011
}

Celem artykułu jest porównanie i ocena rozwiązań wprowadzanych w zakresie podatków w Polsce, Czechach, Słowacji i na Węgrzech w latach 2000-2011 na tle krajów Unii Europejskiej (UE-15) oraz próba odpowiedzi na pytanie, jakie czynniki determinowały zmiany w polityce i praktyce podatkowej, a także jaki był wpływ tych zmian na konkurencyjność gospodarek. W szczególności analiza dotyczy zależności pomiędzy wysokością stawek i przejrzystością podatków a atrakcyjnością krajów dla inwestorów.

Artykuł składa się z czterech punktów oraz podsumowania. W punkcie pierwszym omówiono główne czynniki determinujące zmiany w zakresie podatków w analizowanych krajach w latach 2000-2011. W drugim punkcie przedstawiono strukturę podatków Polski, Czech, Słowacji i Węgier na tle Unii Europejskiej (UE-15). Punkt trzeci zawiera porównanie zmian w podatkach pośrednich i bezpośrednich w analizowanych krajach w latach 2000-2011. W punkcie tym omówiono zmiany związane $\mathrm{z}$ dostosowaniem prawa podatkowego do wymagań unijnych, a także zmiany niezwiązane bezpośrednio $\mathrm{z}$ wejściem do UE. W punkcie czwartym omówiono wpływ zmian podatkowych na konkurencyjność gospodarek.

$\mathrm{Na}$ system podatkowy składa się ogół podatków pobieranych w danym państwie w danym czasie ${ }^{1}$. Podatki sa klasyfikowane według różnych kryteriów ${ }^{2}$. Najbardziej istotny jest podział według kryterium przedmiotowego oraz podział według podmiotu, który ponosi ciężar podatku. Zgodnie z kryterium przedmiotowym wyróżnia się podatki dochodowe (podatki nakładane na przychody pomniejszone o koszty ich uzyskania), podatki majątkowe ${ }^{3}$, podatki konsumpcyjne oraz podatki przychodowe ${ }^{4}$. Według kryterium podmiotu ponoszącego ciężar podatku wyróżnia się natomiast podatki bezpośrednie - ich ciężar ponosi bezpośrednio podmiot, na który podatek został nałożony, oraz

${ }^{1}$ E. Denek, J. Sobiech, J. Wolniak, Finanse publiczne, Wydawnictwo Naukowe PWN, Warszawa 2001.

${ }^{2}$ T. Juja, Finanse publiczne, Wydawnictwo Uniwersytetu Ekonomicznego w Poznaniu, Poznań 2011. Zob. także S. Owsiak, Finanse publiczne. Teoria $i$ praktyka, Wydawnictwo Naukowe PWN, Warszawa 2005; E. Denek, J. Sobiech, J. Wolniak, op. cit.

${ }^{3}$ Podatki majątkowe nie stanowią przedmiotu niniejszej analizy.

${ }^{4}$ Podatki przychodowe odgrywają współcześnie marginalną rolę, więc pominięto je w analizie. 
podatki pośrednie, których ciężar jest przerzucany na inne podmioty ${ }^{5}$. Podatkami pośrednimi są podatki konsumpcyjne i podatki przychodowe, natomiast podatkami bezpośrednimi - podatki dochodowe i majątkowe. Do podatków konsumpcyjnych zaliczane są: podatki akcyzowe (będące tzw. selektywnymi podatkami konsumpcyjnymi, majacymi zastosowanie tylko do niektórych produktów zwanych produktami akcyzowymi), podatek od wartości dodanej (VAT), będący ogólnym podatkiem konsumpcyjnym oraz podatki obrotowe (niemające zastosowania w analizowanych krajach). Do podatków dochodowych natomiast zaliczany jest podatek dochodowy od osób fizycznych (tzw. osobisty podatek dochodowy) - PIT oraz podatek dochodowy od osób prawnych (firm, spółek) - CIT.

W artykule wykorzystano dane Dyrekcji Generalnej ds. Podatków i Unii Celnej Komisji Europejskiej, według których do dochodów podatkowych zalicza się również obowiązkowe składki na ubezpieczenia społeczne (szerokie rozumienie podatków). Składki mają charakter zbliżony do podatku, ponieważ opłacane są przez przedsiębiorstwa w związku z zatrudnieniem pracowników, stanowią więc opodatkowanie czynnika zatrudnienia, wpływając na koszty pracy $^{6}$. Zgodnie $\mathrm{z}$ definicją podatki ,są to pieniężne, przymusowe, bezzwrotne, nieodpłatne ogólne świadczenie nakładane i pobierane przez państwo, [...] nieodpłatność oznacza, że w zamian za wniesione podatki nie przysługuje podatnikom żadne świadczenie wzajemne ze strony państwa" ${ }^{7}$. Natomiast w wypadku ubezpieczeń społecznych składki opłacane są w zamian za usługi ubezpieczeniowe (usługi medyczne, świadczenia emerytalne), z których moga korzystać pracownicy. W rzeczywistości w krajach UE pracownik ma niewielki wpływ na zakres usług, jakimi jest objęty, i ma niewielkie możliwości zmiany ubezpieczyciela, który dostarczałby usługi taniej. Ponadto często istnieje niewielki związek między wysokością składki a ryzykiem, które ona pokrywa. Te czynniki oraz fakt, że składki są obowiązkowe, a ich poziom jest wysoki, sprawiaja, że w analizach UE traktowane są jako podatki.

\section{WPROWADZENIE}

W pierwszej dekadzie XXI w. w analizowanych krajach nastąpiły duże zmiany instytucjonalne. Wiązały się one $\mathrm{z}$ negocjacjami i następnie $\mathrm{z}$ przystąpieniem Polski, Czech, Słowacji i Węgier do Unii Europejskiej (UE), co niosło za sobą konieczność dostosowania prawa podatkowego do wymagań unijnych. Wiązało się to głównie $\mathrm{z}$ harmonizacją przepisów w zakresie podatków pośrednich. Jednocześnie kraje te wprowadzały reformy podatkowe mające na celu umocnienie lub poprawę ich pozycji konkurencyjnej względem krajów członkowskich UE - de facto podjęły one rywalizację na gruncie stosowanej w praktyce polityki podatkowej. W czterech analizowanych gospodarkach obniżono stawki podatku dochodowego od osób prawnych, a na Słowacji i na

\footnotetext{
${ }^{5}$ Szerzej na ten temat zob. T. Juja, op. cit., s. 229.

${ }^{6}$ E. Denek, J. Sobiech, J. Wolniak, op. cit., s. 145.

7 Ibidem, s. 123.
} 
Węgrzech zniesiono podatek od dywidend. W Polsce zredukowano wysokość oraz liczbę stawek podatku dochodowego od osób fizycznych, natomiast Słowacja, a później także Czechy oraz Węgry wprowadziły podatek liniowy.

Kraje środkowoeuropejskie (w tym Polska, Czechy, Słowacja i Węgry) zapoczątkowały redukcję stawek podatków bezpośrednich już pod koniec lat dziewięćdziesiątych XX w. Trend ten następnie objął także wszystkie (choć nie $\mathrm{w}$ równym stopniu) kraje UE-15, które wykorzystały wzrost gospodarczy i towarzyszące mu wysokie dochody podatkowe do obniżania stawek podatków. W latach 2003-2008 w krajach UE-15 trend ten uległ jednak spowolnieniu. Kraje te mogły wykorzystać wzrost gospodarczy do dalszego obniżania podatków, jednak w ocenie Komisji Europejskiej priorytetem stała się redukcja deficytów budżetowych ${ }^{8}$. W tym samym okresie stawki podatków były nadal redukowane w krajach Europy Środkowo-Wschodniej. Trend ten widoczny był więc $\mathrm{w}$ Polsce, Czechach i Słowacji oraz początkowo również na Węgrzech, w których jednak w 2007 r. ze względu na kryzys gospodarczy ponownie zwiększono stawki oraz wprowadzono dodatkowe podatki. W latach 2009-2011 w wyniku kryzysu gospodarczego $\mathrm{w}$ kilku krajach UE-15 oraz $\mathrm{w}$ analizowanych państwach podniesione zostały stawki podatków pośrednich (VAT i podatek akcyzowy - zob. pkt III.1.1.2 i III.1.2.2 niniejszego artykułu).

\section{STRUKTURA DOCHODÓW PODATKOWYCH}

Analiza struktury systemów podatkowych pozwala na określenie względnego znaczenia poszczególnych podatków (grup podatków) w systemie ${ }^{9}$. Charakterystyczną cechą struktury dochodów podatkowych analizowanych krajów jest relatywnie niski udział wpływów z podatków bezpośrednich w dochodach podatkowych oraz wysoki udział składek na ubezpieczenia społeczne w porównaniu z krajami UE-15 (wykres 1 i wykres 3). Udział wpływów z podatków pośrednich w dochodach podatkowych w Polsce, Słowacji i na Węgrzech jest wyższy niż średnia UE-15. W Czechach natomiast podatki konsumpcyjne maja relatywnie mniejsze znaczenie (wykres 2), co jest związane z wysokim udziałem ubezpieczeń społecznych w dochodach podatkowych, które należą do najwyższych na świecie ${ }^{10}$.

W latach 2000-2007 w Czechach wysoki był również udział podatku dochodowego od osób prawnych we wpływach podatkowych w porównaniu z pozostałymi analizowanymi krajami. Od 2008 r. udział podatków bezpośrednich wykazuje tendencję spadkową (wykres 1) ze względu na redukcję stawek podatku dochodowego od osób prawnych oraz wprowadzenie liniowego podatku dochodowego od osób fizycznych (por. pkt III.2.1.2 i III.2.2.2).

${ }^{8}$ European Commission, Taxation Trends in the European Union. Data for the EU Member States, Iceland and Norway, Publications Office of the European Union, Luxemburg 2011, s. 46. Ocena ta nie jest w pełni uprawniona, ponieważ redukcja średniego deficytu budżetowego UE-15 wynikała w dużym stopniu ze wzrostu nadwyżki budżetowej w niektórych krajach UE-15 (Finlandia, Dania, Szwecja, Luksemburg) przy jednoczesnym występowaniu wysokich deficytów w innych krajach UE-15 (Grecja, Portugalia).

${ }^{9}$ E. Denek, J. Sobiech, J. Wolniak, op. cit., s. 135.

${ }^{10} \mathrm{IMF}$, IMF Country Report No 08/40. Czech Republic: Selected Issues, IMF, Washington 2008. 


\section{Wykres 1}

Udział wpływów z podatków bezpośrednich w dochodach podatkowych (\%)

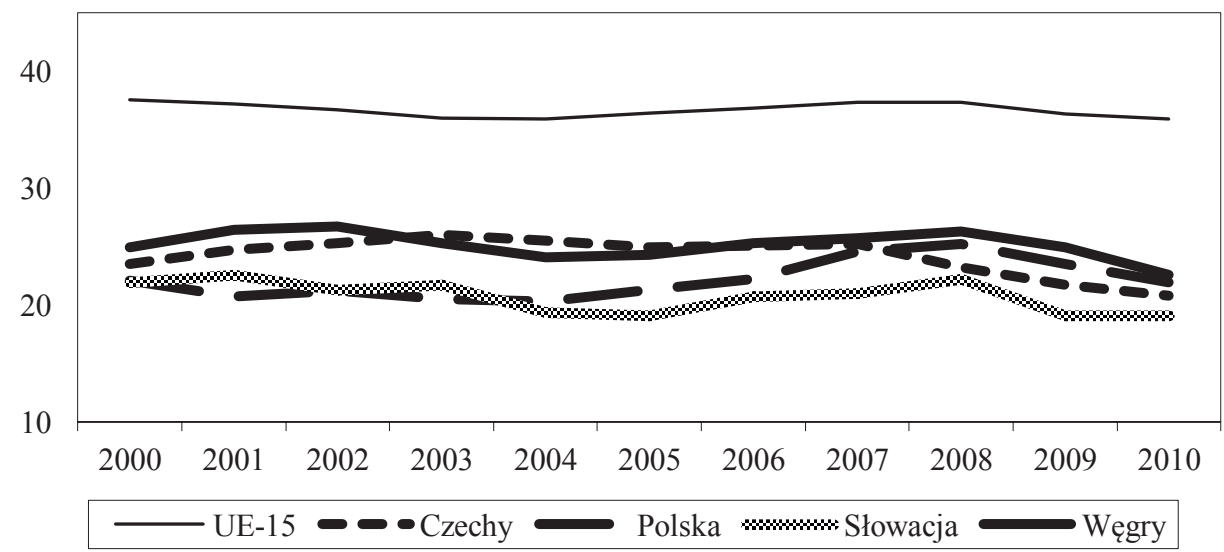

Źródło: Eurostat, 2012.

Węgry odznaczają się wysokimi wpływami z podatków pośrednich. W $2010 \mathrm{r}$. stanowiły one 45,5\% dochodów podatkowych (wykres 2). Udział ten zdecydowanie przewyższa średnią UE-15 ${ }^{11}$; natomiast relatywnie niski jest udział składek na ubezpieczenia społeczne w porównaniu z pozostałymi analizowanymi krajami (wykres 4).

Udział podatków bezpośrednich w dochodach podatkowych Słowacji w analizowanym okresie ulegał stopniowej redukcji ${ }^{12}$. Od 2006 r. trend spadkowy wykazują dochody z tytułu podatków pośrednich, co wynika ze spadku konsumpcji oraz przywrócenia stawki obniżonej VAT w wysokości 10\% w 2007 r. (w 2004 r. zlikwidowano stawkę obniżoną VAT na Słowacji i do końca 2006 r. istniała wyłącznie stawka standardowa w wysokości 19\% - por. pkt III.1.1.2).

Podatki pośrednie (z czego większość stanowią wpływy z tytułu podatku VAT) są najważniejszym źródłem dochodów podatkowych w Polsce. Wysoki jest również udział składek na ubezpieczenia społeczne. Udział ten uległ gwałtownemu wzrostowi w wyniku reformy systemu ubezpieczeń społecznych w 1999 r. (por. pkt III.3) i przeniesienia części wpływów z podatku dochodowego od osób fizycznych do składek na ubezpieczenia społeczne ${ }^{13}$. W latach 2001-2008 udział składek w dochodach podatkowych został stopniowo zredukowany (wykres 3).

${ }^{11}$ Udział podatków pośrednich w dochodach podatkowych Węgier należy do najwyższych w Unii Europejskiej (UE-27). W 2010 r. większy udział podatków pośrednich w dochodach podatkowych miała tylko Bułgaria.

${ }^{12}$ W 2009 r. był on najniższy wśród wszystkich krajów UE-27 i wyniósł 19,2\%.

${ }^{13}$ European Commission, op. cit., s. 133. 


\section{Wykres 2}

Udział wpływów z podatków pośrednich w dochodach podatkowych (\%)



Źródło: Eurostat, 2012.

\section{Wykres 3}

Udział wpływów ze składek na ubezpieczenia społeczne w dochodach podatkowych (\%)

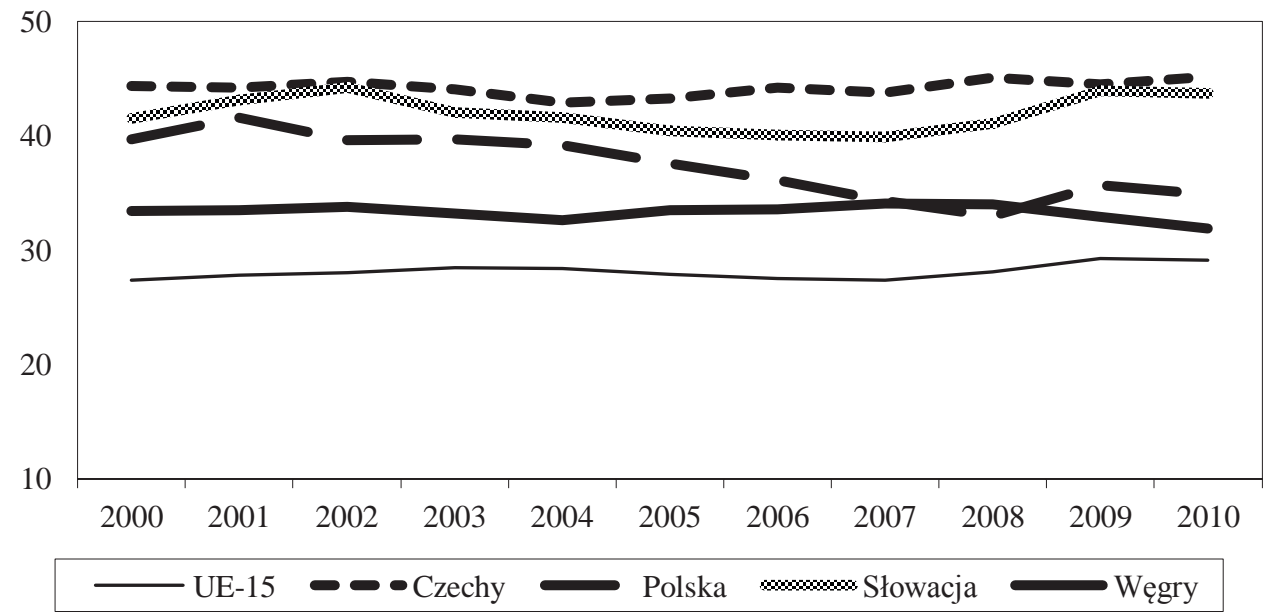

Źródło: Eurostat, 2012. 


\section{KSZTAŁTOWANIE SIE PODATKÓW W LATACH 2000-2011}

\section{Podatki pośrednie}

Znaczące zmiany w zakresie podatków pośrednich w Polsce, Czechach, Słowacji i na Węgrzech związane były z wejściem do Unii Europejskiej oraz koniecznościa dostosowania prawa do wymagań UE. Polityka podatkowa w Unii Europejskiej ma charakter subsydiarny, co oznacza, że stanowienie prawa oraz pobór podatków należy do kompetencji państw członkowskich, którym pozostawiona została duża swoboda w zakresie wyboru systemu podatkowego ${ }^{14}$. Prawo w zakresie podatków pośrednich zostało jednak w wysokim stopniu zharmonizowane, ponieważ może istotnie wpływać na swobodę przepływu towarów i usług na Jednolitym Rynku Europejskim $(\mathrm{JRE})^{15}$. Celem harmonizacji było zapewnienie neutralności podatków pośrednich oraz zniesienie granic podatkowych między krajami członkowskimi.

\subsection{Podatek VAT}

\subsubsection{Unijny system podatku VAT}

Podstawowym dokumentem dotyczacym podatku VAT w UE jest dyrektywa nr 2006/112/WE z 28 listopada 2006 r. w sprawie wspólnego systemu podatku od wartości dodanej ${ }^{16}$. W dyrektywie uregulowano kwestie stawek, wprowadzono ujednolicona podstawę podatku oraz omówiono zasady opodatkowania transakcji wewnątrz wspólnoty ${ }^{17}$. Zgodnie $\mathrm{z}$ art. 98 dyrektywy kraje członkowskie moga stosować jedną lub dwie stawki obniżone, nie mniejsze niż 5\%, jednak tylko w przypadku towarów i usług wymienionych w aneksie III dyrektywy. Stawka standardowa powinna natomiast wynosić co najmniej $15 \%{ }^{18}$.

\subsubsection{Stawki VAT}

W 2004 r. na Słowacji zniesiono stawkę obniżoną podatku VAT (do końca 2002 r. istniała stawka obniżona w wysokości 10\%, a w 2003 r. - stawka 14\%) i pozostawiono wyłącznie stawkę standardową w wysokości 19\%. Reforma

14 J. Małecki, Refleksje o tworzeniu i stosowaniu prawa podatkowego, w: T. Juja, J. Kotliska (red.), Stan i kierunki rozwoju finansów publicznych, ,Zeszyty Naukowe Akademii Ekonomicznej w Poznaniu” nr 90, 2007.

${ }^{15}$ M. Cieślukowski, Kierunki polityki podatkowej Unii Europejskiej, w: E. Denek (red.), Wybrane problemy funkcjonowania systemów podatkowych krajach Unii Europejskiej, „Zeszyty Naukowe Akademii Ekonomicznej w Poznaniu”, nr 67, 2005.

${ }^{16}$ Dyrektywa nr 2006/112/WE z 28 listopada 2006 r. w sprawie wspólnego systemu podatku od wartości dodanej (Dz. Urz. UE L 347/1) opiera się na Szóstej Dyrektywie 77/3/88/EWG z 17 maja 1977 r. dotyczącej harmonizacji przepisów o podatkach obrotowych (Dz. Urz. WE L 145) i łączy w całość wszystkie późniejsze nowelizacje.

${ }^{17}$ R. Lipniewicz, Europejskie prawo podatkowe, Difin, Warszawa 2011.

${ }_{18}$ W. Maruchin, VAT $w$ prawie polskim i prawie wspólnotowym, Oficyna Prawa Polskiego, Warszawa 2009. 





podatku VAT była kluczowa reformą dla powodzenia kolejnych głębokich reform podatku CIT oraz PIT, ponieważ wzrost dochodów z tytułu VAT miał kompensować zmniejszone wpływy budżetowe wynikające $\mathrm{z}$ obniżenia podatków bezpośrednich ${ }^{19}$ (por. pkt III.2.1.2 i III.2.2.2). W Czechach w $2004 \mathrm{r}$. podobnie jak na Słowacji została obniżona stawka standardowa z 22 do 19\%, jednakże stawka obniżona w wysokości $5 \%$ nie została zlikwidowana (tabela 1). $\mathrm{Na}$ Węgrzech w 2004 r. zniesiona została stawka 0\%, ale po wejściu do Unii Europejskiej nadal istniały dwie stawki obniżone.

W Polsce wysokość i ilość stawek pozostała bez zmian do końca 2010 r. W Traktacie akcesyjnym przyznane zostały Polsce okresy przejściowe uprawniające do stosowania dwóch stawek obniżonych poniżej 5\% (w tym czasie istniały w Polsce stawki 0\% oraz 3\%). Derogacje na usługi restauracyjne i usługi budowlane miały obowiązywać do 31 grudnia 2007 r., natomiast na środki do produkcji rolnej oraz na produkty i usługi rolnicze - do 30 kwietnia 2008 r. ${ }^{20}$ Okresy przejściowe przedłużono następnie do 31 grudnia $2010 \mathrm{r}$.

\section{Tabela 2}

Zmiany stawek podatku VAT w krajach UE-15 oraz w Polsce, Czechach, Słowacji i na Węgrzech w latach 2008-2011 (w punktach procentowych)

\begin{tabular}{|c|c|c|c|}
\hline $\mathbf{2 0 0 8}$ & $\mathbf{2 0 0 9}$ & $\mathbf{2 0 1 0}$ & $\mathbf{2 0 1 1}$ \\
\hline Portugalia (-1) & Irlandia $(+0,5)$ & Czechy $(+\mathbf{1})$ & Polska $(+\mathbf{1})$ \\
& Węgry $(+\mathbf{5})$ & Irlandia $(-0,5)$ & Portugalia $(+2)$ \\
& Wielka Brytania $(-2,5)$ & Grecja $(+4)$ & Słowacja (+1) \\
& & Hiszpania $(+2)$ & Wielka Brytania $(+2,5)$ \\
& & Portugalia (+1) & \\
& & Finlandia $(+1)$ & \\
& & Wielka Brytania $(+2,5)$ & \\
\hline
\end{tabular}

Źródło: Dyrekcja Generalna ds. Podatków i Unii Celnej Komisji Europejskiej.

W latach 2009-2011 w wyniku kryzysu gospodarczego w kilku krajach UE-15, a także w Polsce, Czechach, Słowacji i na Węgrzech podniesione zostały stawki podatku VAT ${ }^{21}$ (tabela 2 ). Działania te miały na celu zwiększenie bieżących dochodów budżetowych ${ }^{22}$. W Czechach, Polsce i Słowacji stawka standardowa VAT wzrosła o 1 punkt procentowy, natomiast na Węgrzech - aż o 5 punktów procentowych.

\footnotetext{
19 P. Golias, R. Kicina, Slovak Tax Reform: One Year After, Institute for Economic and Social Reforms, Bratislava 2005.

${ }^{20}$ J. Osiatyński, Finanse publiczne, ekonomia i polityka, Wydawnictwo Naukowe PWN, Warszawa 2006.

${ }^{21}$ Średnia stawka VAT w całej Unii Europejskiej wzrosła w latach 2009-2011 o 2,5 punktu procentowego.

${ }^{22}$ R. Dziemianowicz, Polityka podatkowa jako jeden z elementów zarzadzania finansami publicznymi, w: S. Owsiak, Nowe zarzadzanie finansami publicznymi $w$ warunkach kryzysu, Polskie Wydawnictwo Ekonomiczne, Warszawa 2011.
} 
Najbardziej widoczne zmiany $\mathrm{w}$ polityce podatkowej związane $\mathrm{z}$ reakcja na kryzys gospodarczy widoczne były w opodatkowaniu konsumpcji ${ }^{23}$. Oprócz podniesienia stawek VAT, wiele krajów UE zwiększyło również podatki akcyzowe (zob. pkt III.1.2.2). Stawki VAT najbardziej wzrosły w krajach o wysokim deficycie budżetowym, które pilnie musiały skonsolidować budżet (m.in. Węgry $)^{24}$. Wydajność podatku VAT oraz fakt, że zapewnia on systematyczne i pewne dochody budżetowe, sprawiają, że ze swej istoty bardzo dobrze spełnia funkcję fiskalną: zapewnia środki potrzebne do pokrycia obciążeń publicznych w warunkach kryzysu ${ }^{25}$.

\subsection{Podatki akcyzowe}

\subsubsection{Podatki akcyzowe w Unii Europejskiej}

Obecnie w prawie wspólnotowym obowiązuje dyrektywa nr 2008/118/WE ${ }^{26}$ dotycząca produktów akcyzowych ${ }^{27}$, która zastapiła wcześniejszą dyrektywę nr 92/12/EWG ${ }^{28}$. Prawo wspólnotowe reguluje zasady opodatkowania akcyzą transakcji wewnątrzwspólnotowych, czyli obrotu wyrobami akcyzowymi pomiędzy państwami członkowskimi UE. Uregulowane zostały jedynie stawki minimalne akcyz na poszczególne wyroby akcyzowe, powyżej których państwa członkowskie moga dowolnie kształtować wysokość podatku. Produktami akcyzowymi, które podlegają harmonizacji w Unii Europejskiej, są wyroby alkoholowe, wyroby tytoniowe i produkty energetyczne ${ }^{29}$. Państwa członkowskie moga nakładać podatki akcyzowe także na inne wyroby (np. samochody, kosmetyki). Opodatkowanie tych wyrobów nie jest jednak regulowane prawem wspólnotowym i należy do kompetencji państw członkowskich.

\subsubsection{Stawki podatków akcyzowych w latach $2000-2011$}

W reakcji na kryzys gospodarczy w wielu krajach EU obok zwiększenia stawek VAT (zob. pkt III.1.1.2) podniesiono także stawki podatków akcyzowych (tabela 3).

W 2009 r. na Węgrzech został podniesiony podatek akcyzowy na wyroby energetyczne oraz wyroby alkoholowe i tytoniowe. W następnym roku

\footnotetext{
${ }^{23}$ Por. P. Ciżkowicz, P. Opala, A. Rzońca, Rola systemu podatkowego przed, w trakcie i po kryzysie finansowym, „Ruch Prawniczy, Ekonomiczny i Socjologiczny” 2012, z. 1.

${ }^{24}$ R. Mooij, M. Keen, ,Fiscal Devaluation” and Fiscal Consolidation: The VAT in Troubled Times, IMF, Washington 2012.

${ }_{25}^{25}$ T. Famulska, VAT jako instrument polityki fiskalnej $w$ warunkach kryzysu gospodarczego, w: S. Owsiak (red.), op. cit.

${ }^{26}$ Dyrektywa nr 2008/118/WE z 16 grudnia 2008 r. w sprawie ogólnych zasad dotyczących podatku kcyzowego, uchylająca dyrektywę nr 92/12/EWG (Dz. Urz. UE L 9/12).

${ }^{27}$ R. Lipniewicz, op. cit.

${ }^{28}$ Dyrektywa nr 92/12/EWG z 25 lutego 1992 r. w sprawie ogólnych warunków dotyczących wyrobów objętych podatkiem akcyzowym, ich przechowywania, przepływu oraz kontrolowania (Dz. Urz. L 76).

${ }^{29}$ D. Mączyński, Akcyza w prawie Unii Europejskiej i w prawie Stanów Zjednoczonych Ameryki Pótnocnej, „Ruch Prawniczy, Ekonomiczny i Socjologiczny” 2008, z. 3.
} 


\section{Tabela 3}

Zmiany stawek podatku akcyzowego w 2009 r. i w pierwszej połowie 2010 r. w krajach UE-15 oraz w Polsce, Czechach, Słowacji i na Węgrzech

\begin{tabular}{|l|c|c|}
\hline \multicolumn{2}{|c|}{ Produkty energetyczne } & $\begin{array}{c}\text { Wyroby tytoniowe } \\
\text { i alkoholowe }\end{array}$ \\
\hline Zwiększenie stawek & Węgry, Hiszpania, Grecja & Finlandia, Wegry, Hiszpania \\
\hline Zmniejszenie stawek & Włochy & 2010 \\
\hline \multicolumn{3}{|c|}{} \\
\hline Zwiększenie stawek & $\begin{array}{r}\text { Czechy, Dania, Grecja, } \\
\text { Wegry }\end{array}$ & $\begin{array}{c}\text { Czechy, Dania, Finlandia, } \\
\text { Grecja, Wegry, Polska }\end{array}$ \\
\hline Zmniejszenie stawek & Polska, Słowacja & \\
\hline
\end{tabular}

Źródło: Dyrekcja Generalna ds. Podatków i Unii Celnej Komisji Europejskiej.

w Czechach oraz ponownie na Węgrzech wzrósł podatek akcyzowy na produkty energetyczne, natomiast w Polsce zwiększono podatek akcyzowy na wyroby tytoniowe i alkoholowe. W 2010 r. w Polsce i Słowacji zredukowany został podatek akcyzowy na produkty energetyczne (tabela 3 ).

\section{Podatki bezpośrednie}

Jak już podkreślono w punkcie III.1, nowe kraje członkowskie przed wejściem do Unii Europejskiej musiały wdrożyć prawo wspólnotowe do ustawodawstwa krajowego. Mimo że podatki bezpośrednie nie zostały zharmonizowane w Unii, podjęto jednak pewne działania mające na celu harmonizację również podatków dochodowych ${ }^{30}$. Ich celem jest wyeliminowanie podwójnego opodatkowania, ochrona państw przed unikaniem opodatkowania oraz zapobieganie nieuczciwej konkurencji podatkowej ${ }^{31}$. Jednocześnie kraje Europy Srodkowej i Wschodniej wprowadzały reformy podatkowe mające na celu poprawę pozycji konkurencyjnej względem krajów UE-15.

${ }^{30}$ M. Hybka, Harmonizacja opodatkowania dochodów przedsiębiorstw w Unii Europejskiej świetle postanowień strategii lizbońskiej, w: T. Juja, (red), Opodatkowanie przedsiębiorców w warunkach cztonkostwa Polski w Unii Europejskiej. Zagadnienia wybrane, „Zeszyty Naukowe Akademii Ekonomicznej w Poznaniu", nr 101, 2008.

${ }^{31}$ R. Dziemianowicz, Polityka podatkowa $w$ państwach UE: wspótczesne trendy $i$ wyzwania, w: T. Juja (red.), Dylematy i wyzwania finansów publicznych, „Zeszyty Naukowe Uniwersytetu Ekonomicznego w Poznaniu", nr 141, 2010, s. 397 i n. 


\subsection{Podatek dochodowy od osób prawnych}

\subsubsection{Dostosowanie prawa podatkowego do wymagań Unii Europejskiej}

W Unii Europejskiej trwaja prace nad harmonizacja podatku dochodowego od osób prawnych ${ }^{32}$. Propozycje stworzenia wspólnej skonsolidowanej podstawy opodatkowania (CCCTB) ${ }^{33}$ nie zostały jednak dotąd wprowadzone w życie. W tym obszarze prawa podatkowego przyjęto jednak następujące dyrektywy mające na celu eliminację barier działalności transgranicznej ${ }^{34}$ :

a) dyrektywa Rady $\mathrm{nr}$ 90/435/EWG ${ }^{35}$ wyeliminowała podatek u źródła nakładany na dywidendy wypłacane pomiędzy spółkami powiązanymi, prowadzącymi działalność na terenie różnych krajów $\mathrm{UE}^{36}$. W $2003 \mathrm{r}$. została przyjęta dyrektywa nr 2003/123/WE ${ }^{37}$ poszerzajacca zakres dyrektywy nr 90/435/EWG oraz ją ulepszająca poprzez obniżenie progu udziałów w spółce powiązanej uprawniającego do zwolnienia z podatku u źródła. Przed 2005 r. spółka dominująca musiała posiadać co najmniej $25 \%$ udziałów w spółce zależnej, aby móc skorzystać ze zwolnienia. Próg ten był stopniowo zmniejszany i od 1 stycznia 2009 r. wynosi $10 \%^{38}$.

b) Celem dyrektywy $\mathrm{nr} 90 / 434 / \mathrm{EWG}^{39}$ było usunięcie przeszkód podatkowych do transgranicznych reorganizacji przedsiębiorstw zlokalizowanych w dwóch lub kilku krajach UE poprzez odroczenie opodatkowywania dochodów i zysków kapitałowych wynikających z przekształceń przedsiębiorstw. Wprowadzone rozwiązania miały na celu zapobieżenie dyskryminacji pod względem podatkowym $\mathrm{w}$ traktowaniu transgranicznych reorganizacji przedsiębiorstw

${ }^{32}$ M. Kluzek, Znaczenie konkurencji podatkowej dla rozmieszczenia bezpośrednich inwestycji zagranicznych $w$ Unii Europejskiej, Wydawnictwo Uniwersytetu Ekonomicznego w Poznaniu, Poznań 2010.

${ }^{33}$ J. Irwin-Grzyńska, Wspólna skonsolidowana korporacyjna podstawa opodatkowania - nowy paradygmat opodatkowania podatkiem dochodowym przedsiębiorstw w Unii Europejskiej, w: J. Sobiech (red.), Kierunki zmian $w$ finansach przedsiębiorstwa, „Zeszyty Naukowe Uniwersytetu Ekonomicznego w Poznaniu", nr 142, 2010.

${ }^{34}$ M. Hybka, op. cit.

${ }^{35}$ Dyrektywa nr 90/435/EWG z 23 lipca 1990 r. w sprawie wspólnego systemu opodatkowania stosowanego w przypadku spółek dominujących i spółek zależnych różnych Państw Członkowskich (Dz. Urz. L 225).

${ }^{36}$ E. Małecka-Ziembińska, Opodatkowanie dywidend $w$ świetle unijnych $i$ polskich przepisów, w: T. Juja (red.), Opodatkowanie przedsiębiorców.

${ }^{37}$ Dyrektywa nr 2003/123/WE z 22 grudnia 2003 r. zmieniająca dyrektywę nr 90/435/EWG w sprawie wspólnego systemu opodatkowania stosowanego w przypadku spółek dominujacych i spółek zależnych różnych Państw Członkowskich (Dz. Urz. L 007). Kraje członkowskie musiały wprowadzić dyrektywę nr 2003/123/WE do ustawodawstwa krajowego do 31 grudnia 2004 r., również kraje, które przestąpiły do UE 1 maja 2004 r. (nie było okresów przejściowych).

${ }^{38}$ H. Litwińczuk, K. Tetłak, Ł. Adamczyk, Podatki bezpośrednie. Prawo polskie a prawo wspólnotowe, Oficyna Prawa Polskiego, Warszawa 2009.

${ }^{39}$ Dyrektywa nr 90/434/EWG z 23 lipca 1990 r. w sprawie wspólnego systemu opodatkowania mającego zastosowanie w przypadku łączenia, podziałów, wnoszenia aktywów i wymiany udziałów, dotyczących spółek różnych Państw Członkowskich (Dz. Urz. L 225). 
w porównaniu z identycznymi zdarzeniami dotyczącymi spółek jednego państwa członkowskiego ${ }^{40}$. Dyrektywa została w 2005 r. znowelizowana ${ }^{41}$.

c) Dyrektywa nr 2003/49/WE ${ }^{42}$ została stworzona w celu wyeliminowania podatku u źródła w zakresie transgranicznych płatności odsetek i należności licencyjnych ${ }^{43}$. Niektóre kraje członkowskie wynegocjowały okresy przejściowe na wprowadzenie dyrektywy do prawa krajowego (tabela 4).

\section{Tabela 4}

Okresy przejściowe dla dyrektywy nr 2003/49/WE

\begin{tabular}{|c|c|c|}
\hline Kraj & Odsetki & Należności licencyjne \\
\hline Czechy & - & 1 lipca $2011 \mathrm{r}$. \\
\hline Polska & 1 lipca $2013 \mathrm{r}$. & 1 lipca $2013 \mathrm{r}$. \\
\hline
\end{tabular}

Źródło: Dyrekcja Generalna ds. Podatków i Unii Celnej Komisji Europejskiej.

Dyrektywa nr 2003/49/WE weszła w życie na Słowacji i Węrzech od razu po wejściu tych państw do Unii Europejskiej. Natomiast Czechy i Polska wynegocjowały okresy przejściowe (tabela 4). Czechy musiały wdrożyć dyrektywę do 1 lipca 2011 r. W Polsce przepisy unijne w zakresie transgranicznych płatności odsetek oraz należności licencyjnych będą obowiązywały dopiero od 1 lipca 2013 r.

\subsubsection{Reformy podatkowe}

W 1995 r. stawki CIT w Polsce, Czechach i Słowacji kształtowały się na poziomie zbliżonym do średniej stawki w krajach EU-15 (wykres 4). Od końca lat dziewięćdziesiątych XX w. w Unii Europejskiej widoczny był trend obniżania stawek podatku dochodowego od osób prawnych. Trend ten, zapoczątkowany przez nowe kraje członkowskie, objął również kraje UE-15 ${ }^{44}$. Stawki CIT zostały najbardziej obniżone w krajach Europy Srodkowo-Wschodniej. W okresie ostatnich 15 lat redukcji uległa również średnia stawka podatku dochodowego w krajach EU-15, trend ten nie był jednak tak silny jak w analizowanych krajach (wykres 4).

Wysokość stawek CIT ewoluowała w podobny sposób w Polsce, Słowacji i Czechach. Stawki zostały obniżone z wysokości odpowiednio 30\%, 29\% i 31\%

${ }^{40}$ H. Litwińczuk, K. Tetłak, Ł. Adamczyk, op. cit.

${ }^{41}$ Dyrektywa nr 2005/19/WE z 17 lutego 2005 r. zmieniająca dyrektywę Rady nr 90/434/EWG $\mathrm{w}$ sprawie wspólnego systemu opodatkowania mającego zastosowanie w przypadku łączenia, podziałów, wnoszenia aktywów i wymiany udziałów, dotyczących spółek różnych Państw Członkowskich (Dz. Urz. L 058).

${ }^{42}$ Dyrektywa nr 2003/49/WE z 3 czerwca 2003 r. w sprawie wspólnego systemu opodatkowania stosowanego do odsetek oraz należności licencyjnych między powiązanymi spółkami różnych Państw Członkowskich (Dz. Urz. L 157).

${ }^{43}$ H. Litwińczuk, K. Tetłak, Ł. Adamczyk, op. cit.

${ }^{44}$ European Commission, op. cit., s. 62. 


\section{Wykres 4}

Stawki CIT w Unii Europejskiej (\%)



19951996199719981999200020012002200320042005200620072008200920102011

UE-15 $\bullet \bullet-C z e c h y$

Polska $\quad$ Słowacja

Węgry

Źródło: Eurostat, 2011.

w 2000 r. do poziomu 19\%. Słowacja i Polska wprowadziły stawkę 19\% już w 2004 r., z kolei Czechy - dopiero w 2010 r. Na Węgrzech natomiast już w 1995 r. obowiązywała stawka CIT w wysokości 18\%. Była to stawka znacząco niższa niż w pozostałych analizowanych krajach. Dodatkowo na Węgrzech istnieje podatek lokalny w wysokości do $2 \%{ }^{45}$ (władze lokalne moga dowolnie kształtować wysokość stawki do wysokości 2). W 2004 r. stawka CIT została obniżona do 16\%. Od 1 sierpnia 2006 r. wprowadzono podatek solidarnościowy, który dodatkowo zwiększył obciążenie podatkowe przedsiębiorstw węgierskich. Od 1 stycznia 2010 r. poszerzono podstawę opodatkowania i zwiększono stawkę CIT do wysokości 19\%. Jednocześnie zniesiony został podatek solidarnościowy ${ }^{46}$.

\subsubsection{Opodatkowanie dywidend}

Zysk netto przedsiębiorstw wypłacany właścicielom (osobom fizycznym i osobom prawnym) w postaci dywidend podlega w Polsce i w Czechach ponownemu opodatkowaniu (tabela 5). Podatek dochodowy jest naliczany i potracany przez spółkę wypłacającą dywidendę. W przypadku zagranicznych odbiorców dywidend zastosowanie mają umowy o unikaniu podwójnego opodatkowania. Jeśli spełnione sa warunki określone w dyrektywie nr 2003/123/WE (zob. pkt III.2.1.1.a), podatek od dywidend nie jest pobierany.

W Polsce i Czechach dywidendy podlegają opodatkowaniu podatkiem dochodowym w wysokości odpowiednio 19\% i 15\% (tabela 5). Słowacja już w 2004 r.

${ }^{45}$ KPMG, Investment in Hungary, KPMG Hungaria Kft., Budapest 2010.

${ }^{46}$ KPMG, op. cit. 
Tabela 5

Opodatkowanie dywidend

\begin{tabular}{|c|c|c|c|}
\hline Czechy & Polska & Słowacja & Węgry \\
\hline $\begin{array}{l}\text { Stawka podatku do- } \\
\text { chodowego od dywi- } \\
\text { dend wynosi 15\%. } \\
\text { Podatek u źródła na- } \\
\text { kładany jest na dy- } \\
\text { widendy wypłacane } \\
\text { zarówno osobom fi- } \\
\text { zycznym, jak i spół- } \\
\text { kom, z wyłączeniem } \\
\text { spółek, które speł- } \\
\text { niaja wymagania dy- } \\
\text { rektywy nr 2003/ } \\
\text { 123/WE. }\end{array}$ & $\begin{array}{l}\text { Stawka podatku do- } \\
\text { chodowego od dywi- } \\
\text { dend wynosi } 19 \% \text {. } \\
\text { Podatek u źródła na- } \\
\text { kładany jest na dy- } \\
\text { widendy wypłacane } \\
\text { zarówno osobom fi- } \\
\text { zycznym, jak i spół- } \\
\text { kom. Spółki speł- } \\
\text { niające wymagania } \\
\text { dyrektywy nr 2003/ } \\
\text { 123/WE są zwolnio- } \\
\text { ne z opodatkowania. }\end{array}$ & $\begin{array}{l}\text { W } 2004 \text { r. podatek od } \\
\text { dywidend został cał- } \\
\text { kowicie zniesiony. }\end{array}$ & $\begin{array}{l}\text { Od } 1 \text { stycznia } 2004 \text { r. } \\
\text { obowiązywał poda- } \\
\text { tek w wysokości } 20 \% \\
\text { nakładany na dywi- } \\
\text { dendy wypłacane na } \\
\text { rzecz osób fizycz- } \\
\text { nych na terenie Wę- } \\
\text { gier lub na rzecz u- } \\
\text { działowcy zagranicz- } \\
\text { nego, z wyłączeniem } \\
\text { spółek spełniajaccych } \\
\text { wymagania dyrekty- } \\
\text { wy nr } 2003 / 123 / \text { WE. } \\
\text { Podatek nie był po- } \\
\text { bierany od dywidend } \\
\text { wypłacanych przed- } \\
\text { siębiorstwom weggier- } \\
\text { skim. Od } 1 \text { stycznia } \\
2006 \text { r. podatek od } \\
\text { dywidend został cał- } \\
\text { kowicie zniesiony. }\end{array}$ \\
\hline
\end{tabular}

Źródło: opracowanie własne na podstawie Taxation Trends 2011.

całkowicie wyeliminowała podatek od dywidend, a w 2006 r. podatek ten został zniesiony także na Węgrzech.

\subsection{Podatek dochodowy od osób fizycznych}

\subsubsection{Dostosowanie prawa podatkowego do wymagań Unii Europejskiej}

Komisja Europejska wyraziła opinię, że podatek dochodowy od osób fizycznych pozostanie w kompetencji państw członkowskich nawet wtedy, gdy osiagnięty zostanie wyższy niż obecnie poziom integracji ${ }^{47}$. Jednocześnie dąży się do koordynacji na poziomie UE niektórych kwestii w celu eliminacji przeszkód w działalności na wspólnym rynku, a także w celu przeciwdziałania podwójnemu opodatkowaniu i uchylaniu się od opodatkowania ${ }^{48}$. W 2003 r. wprowadzona została dyrektywa $\mathrm{nr} 2003 / 48 / \mathrm{WE}^{49}$ dotycząca opodatkowania

\footnotetext{
${ }^{47}$ European Commission, Tax Policy in the European Union - Priorities for the Years Ahead, COM (2001), Brussels 2001.

${ }^{48}$ M. Cieślukowski, op. cit.

${ }^{49}$ Dyrektywa nr 2003/48/WE z 3 czerwca 2003 r. w sprawie opodatkowania dochodów z oszczędności w formie wypłacanych odsetek (Dz. Urz. L 157).
} 
dochodów z oszczędności w formie odsetek ${ }^{50}$, której celem było przeciwdziałanie uchylaniu się od opodatkowania poprzez relokowanie oszczędności za granicę. Dyrektywa ma zastosowanie do odsetek od kapitału wypłacanych osobom fizycznym zamieszkałym w kraju UE innym niż kraj, z którego pochodzą odsetki. Płatności takie podlegaja opodatkowaniu zgodnie z prawem kraju, którego rezydentem jest osoba otrzymująca płatność z tytułu odsetek.

\subsubsection{Reformy podatkowe}

W Unii Europejskiej widoczny jest trend do obniżana stawek podatku dochodowego od osób fizycznych. Największa redukcja stawek nastąpiła w krajach Europy Środkowo-Wschodniej i była związana z wprowadzeniem podatku liniowego ${ }^{51}$. Wprowadzanie podatku liniowego jest charakterystyczne dla państw rozwijających się (głównie małych), podobny trend nie występuje w krajach Europy Zachodniej ${ }^{52}$. Często obniżeniu stawek towarzyszyło poszerzenie podstawy opodatkowania. Stawki podatku dochodowego od osób fizycznych uległy nieznacznej redukcji w krajach EU-15 w porównaniu z analizowanymi krajami (wykres 5). Średnia stawka PIT $^{53}$ w 2011 r. w krajach UE-15

\section{Wykres 5}

Najwyższa stawka PIT (\%)

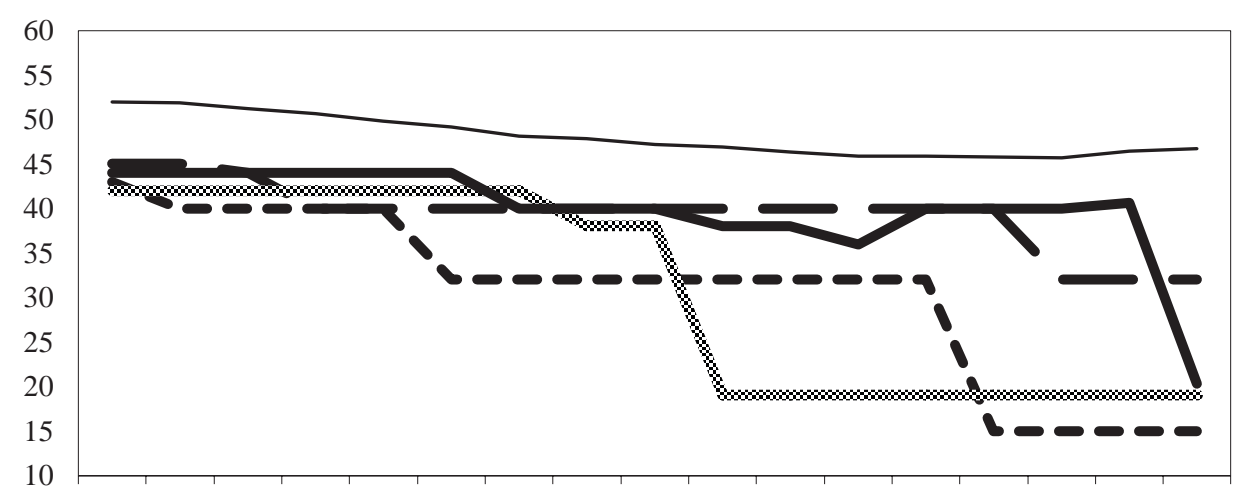

19951996199719981999200020012002200320042005200620072008200920102011

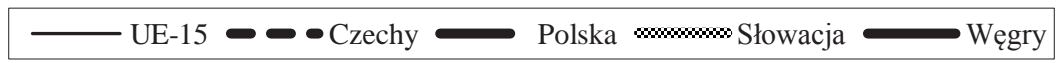

Źródło: Dyrekcja Generalna ds. Podatków i Unii Celnej Komisji Europejskiej.

${ }^{50}$ H. Litwińczuk, K. Tetłak, Ł. Adamczyk, op. cit.

51 Podatek liniowy został wprowadzony w Rumunii, Bułgarii, Czechach, Słowacji i na Węgrzech.

${ }^{52}$ E. Małecka-Ziembińska, Wybrane zagadnienia konkurencji podatkowej oraz ich egzemplifikacja na przykładzie podatku dochodowego od osób fizycznych, w: T. Juja (red.), Dylematy i wyzwania finansów publicznych, s. 460.

${ }^{53}$ Pod uwagę była brana najwyższa stawka PIT. 


\section{Tabela 6}

Stawki PIT (\%)

\begin{tabular}{|c|c|r|r|r|}
\hline Rok & Czechy & Polska & Słowacja & Wegry \\
\hline 2000 & $15,20,25,32$ & $19,30,40$ & $\begin{array}{r}12,20,25,30, \\
35,40,42\end{array}$ & $20,30,40$ \\
\hline 2001 & $15,20,25,32$ & $19,30,40$ & $\begin{array}{r}12,20,25,30, \\
35,40,42\end{array}$ & $20,30,40$ \\
\hline 2002 & $15,20,25,32$ & $19,30,40$ & $10,20,28,35$, & $20,30,40$ \\
& & & 38 & $20,30,40$ \\
\hline 2003 & $15,20,25,32$ & $19,30,40$ & $10,20,28,35$, & $18,26,38$ \\
\hline 2004 & $15,20,25,32$ & $19,30,40$ & 38 & 18,38 \\
\hline 2005 & $15,20,25,32$ & $19,30,40$ & 19 & 18,36 \\
\hline 2006 & $12,19,25,32$ & $19,30,40$ & 19 & 19 \\
\hline 2007 & $12,19,25,32$ & $19,30,40$ & 19 & $18,36+$ podatek solidarnościowy \\
\hline 2008 & 15 & $19,30,40$ & 19 & $18,36+$ podatek solidarnościowy \\
\hline 2009 & 15 & 18,32 & 19 & 17,32 \\
\hline 2010 & 15 & 18,32 & 19 & 16 \\
\hline 2011 & 15 & 18,32 & & \\
\hline
\end{tabular}

Źródło: OECD, Dyrekcja Generalna ds. Podatków i Unii Celnej Komisji Europejskiej.

wynosiła 48,1\% i była znacząco wyższa niż stawki w Polsce, Czechach, Słowacji i na Węgrzech (odpowiednio: $32 \%, 15 \%, 19 \%$ i 16\%). Ma to odzwierciedlenie w udziale wpływów $\mathrm{z}$ podatków bezpośrednich $\mathrm{w}$ dochodach podatkowych (zob. pkt II.2). Podatki dochodowe stanowią bardzo ważne źródło wpływów budżetowych w krajach UE-15, natomiast znaczenie tych podatków w analizowanych krajach jest relatywnie mniejsze.

W wyniku kryzysu gospodarczego niektóre kraje EU-15 (m.in. Grecja, Włochy, Portugalia, Hiszpania) podniosły stawki PIT ${ }^{54}$. W latach 2010-2011 średnia stawka PIT w krajach UE-15 wzrosła o 0,5 punktu procentowego ${ }^{55}$. Stawki PIT w Polsce, Czechach i Słowacji nie uległy w tym czasie zmianie. Na Wegrzech natomiast w latach 2010-2011 stawki PIT zostały zredukowane (tabela 6).

Polska, Czechy, Słowacja i Węgry przed wejściem do Unii Europejskiej miały progresywny system podatku dochodowego od osób fizycznych (tabela 6). W 2000 r. na Słowacji istniało aż 7 progów podatkowych, w Czechach - 4, a w Polsce i na Węgrzech - 3. W 2002 r. liczbę stawek zmniejszono na Słowacji do 5, a 2004 r. wprowadzono podatek liniowy w wysokości $19 \%$.

\footnotetext{
${ }^{54}$ Stawki PIT zostały w tym czasie podniesione tylko w dwóch nowych krajach UE - w 2010 r. na Łotwie i w 2011 r. na Litwie [European Commission 2011, s. 99].

${ }^{55}$ European Commission, op. cit., s. 99.
} 
W 2008 r. podatek liniowy został wprowadzony również w Czechach (15\%), w których jednocześnie podstawa opodatkowania poszerzona została o składki na ubezpieczenia społeczne opłacane przez pracodawcę (stanowiące 34\% wynagrodzenia brutto). W Polsce obowiązujące do końca 2008 r. trzy stawki PIT (19\%, 30\% i 40\%) zastapione zostały od 2009 r. dwiema stawkami w wysokości $18 \%$ i $32 \%$.

Na Węgrzech w 2004 r. obowiązywały trzy stawki PIT (tabela 6) ${ }^{56}$. Od 1 stycznia 2005 r. trzy stawki zostały zastąpione dwiema, a od 2006 r. najwyższą stawkę zmniejszono o 2 punkty procentowe. Od 1 stycznia 2007 r. osoby fizyczne, których dochód przekracza 6748850 forintów, płacą dodatkowy podatek solidarnościowy w wysokości $4 \%^{57}$. Od $2010 \mathrm{r}$. do podstawy opodatkowania podatkiem dochodowym doliczana jest składka na ubezpieczenie społeczne opłacana przez pracodawcę (27\% wynagrodzenia brutto). W $2010 \mathrm{r}$. stawki PIT zmniejszono z $18 \%$ i $36 \%$ do $17 \%$ i $32 \%$ oraz zniesiono podatek solidarnościowy. Od pierwszego stycznie $2011 \mathrm{r}$. wprowadzony został przez podatek liniowy w wysokości $16 \%$. W $2011 \mathrm{r}$. do podstawy opodatkowania nadal doliczane są składki na ubezpieczenia społeczne płacone przez pracodawcę (27\% wynagrodzenia brutto).

\section{Ubezpieczenia społeczne}

Reformy emerytalne w krajach Europy Środkowo-Wschodniej nie zostały przeprowadzone w ,,pierwszej fali” reform ${ }^{58}$. Systemy emerytalne mogły istnieć w dotychczasowym kształcie, nie trzeba ich było tworzyć od podstaw. Były one jednak niedostosowane do sytuacji bezrobocia. Wzrost wydatków systemów emerytalnych i jednoczesny spadek wpływów powodował, że rosła świadomość konieczności wprowadzenia reform, aby zapewnić ich długookresowe funkcjonowanie. Celem reform miało być zastąpienie rozwiązań publicznych i repartycyjnych przez prywatne i kapitałowe. Spośród ośmiu byłych krajów socjalistycznych, które przystapiły do Unii Europejskiej w 2004 r., tylko Czechy i Słowenia nie przeprowadziły reformy systemu emerytalnego ${ }^{59}$.

Najwcześniej, gdyż już w 1998 r., reformę wprowadziły Węgry, a następnie Polska (w 1999 r.). Na Słowacji nowy system emerytalny został wprowadzony łącznie $\mathrm{z}$ pakietem reform podatkowych (por. pkt III.1.1.2, III.2.1.2, III.2.1.3, III.2.2.2) w $2004 \mathrm{r}$. Nowe systemy emerytalne oparte zostały na trzech filarach: obowiązkowym publicznym ubezpieczeniu, obowiązkowym prywatnym ubezpieczeniu oraz dobrowolnym prywatnym ubezpieczeniu ${ }^{60}$. W Czechach natomiast pojawiały się propozycje reformy emerytalnej ${ }^{61}$, żadna z propozycji nie została jednak wprowadzona w życie.

\footnotetext{
${ }^{56} \mathrm{KPMG}$, Investment in Hungary, KPMG Hungaria Kft., Budapest 2004.

${ }^{57} \mathrm{KPMG}$, Investment in Hungary, KPMG Hungaria Kft., Budapest 2007.

${ }_{58}$ M. Żukowski, Reformy emerytalne w Europie, Wydawnictwo Akademii Ekonomicznej w Poznaniu, Poznań 2006.

${ }^{59}$ Ibidem, s. 29.

60 Ibidem.

${ }^{61}$ D. Botman, A. Tuladhar, Tax and Pension Reform in the Czech Republic-Implications for Growth and Debt Sustainability, IFM Working Papar WP/08/125, IMF, Washington 2008.
} 
Na Słowacji do prywatnych funduszy trafia 9\% dochodów brutto, w Polsce od 1999 r. do OFE trafiało 7,3\% dochodów brutto, natomiast od 2011 r. $-2,3 \%$. Do prywatnych funduszy emerytalnych Węgrzy do końca 2010 r. przekazywali 8\% swoich zarobków brutto. W 2011 r. na Węgrzech prywatne fundusze emerytalne zostały zlikwidowane. Obecnie cała składka, która wcześniej przekazywana była do prywatnych funduszy emerytalnych, trafia do budżetu państwa ${ }^{62}$.

\section{REFORMY PODATKOWE A KONKURENCYJNOŚĆ}

System podatkowy jest jednym z czynników wpływających na konkurencyjność państw. Analiza konkurencyjności gospodarek podejmowana jest między innymi przez Światowe Forum Ekonomiczne. Global Competitiveness Report (GCR) publikowany przez tę organizację zawiera ranking konkurencyjności państw (Global Competitiveness Index - GCI), powstały na podstawie analizy 12 kluczowych obszarów (są to instytucje, infrastruktura, otoczenie makroekonomiczne, zdrowie i edukacja podstawowa, szkolnictwo wyższe, efektywność rynku towarów, efektywność rynku pracy, rozwój rynków finansowych, gotowość technologiczna, rozmiar rynku, dojrzałość biznesowa oraz innowacje). Wskaźnikami branymi pod uwage przy ocenie efektywności rynku towarów sa między innymi zakres i wpływ podatków oraz stopa podatkowa. Wskaźnik ten pochodzi z raportu Doing Business Banku Światowego i jest obliczany jako relacja podatków do zysków przedsiębiorstw - pod uwagę brany jest podatek dochodowy, składki na ubezpieczenia społeczne opłacane przez pracodawcę oraz pozostałe podatki.

Najwyższą wśród analizowanych krajów pozycję w rankingu pod względem znaczenia podatków dla konkurencyjności zajmuje Słowacja (tabela 7), co odzwierciedla wpływ reform podatkowych (w 2004 r.) mających na celu poprawę konkurencyjności i atrakcyjności Słowacji dla inwestorów. Z roku na rok ocena jest jednak coraz niższa (w raporcie 2008-2009 Słowacja znalazła się na bardzo wysokim 17 miejscu, natomiast w raporcie 2011-2012-dopiero na pozycji 49).

Trochę gorzej oceniane są Czechy (45-61 miejsce w rankingu). Bardzo nisko natomiast oceniana jest atrakcyjność Węgier (jedne z ostatnich miejsc w rankingu wśród wszystkich ocenianych państw), co wiąże się z częstym zmianami stawek, wprowadzaniem dodatkowych podatków, dużą zmiennością polityki podatkowej. Również Polska oceniana jest pod tym względem relatywnie nisko (w raporcie 2008-2009 na 128 miejscu wśród 134 analizowanych państw, w następnych latach nieznacznie wyżej).

Wybrane kraje UE-15 również oceniane są pod względem wpływu opodatkowania na konkurencyjność relatywnie nisko (tabela 7). Wyjątek stanowi Irlandia, która w raporcie 2008-2009 znalazła się na 18 miejscu. Francja, Niemcy oraz kraje skandynawskie znajdują się na odległych pozycjach w rankingu.

${ }^{62}$ European Commission, Taxation Trends in the European Union. Data for the EU Member States, Iceland and Norway, Publications Office of the European Union, Luxemburg 2012. 


\section{Tabela 7}

Pozycja Polski, Czech, Słowacji i Węgier w rankingu konkurencyjności gospodarek pod względem zakresu i wpływu podatków oraz stopy podatkowej na tle głównych krajów UE-15 oraz Danii, Szwecji i Irlandii

\begin{tabular}{|c|c|c|c|c|c|}
\hline & & $\begin{array}{c}\text { 2008-2009 } \\
\text { (ranking } \\
134 \text { państw) }\end{array}$ & $\begin{array}{c}2009-2010 \\
\text { (ranking } \\
133 \text { państw) }\end{array}$ & $\begin{array}{c}2010-2011 \\
\text { (ranking } \\
139 \text { państw) }\end{array}$ & \begin{tabular}{|c}
$2011-2012$ \\
(ranking \\
142 państw)
\end{tabular} \\
\hline \multirow[t]{2}{*}{ Czechy } & Zakres oraz wpływ podatków & 61 & 45 & 49 & 57 \\
\hline & Stopa podatkowa & 82 & 85 & 91 & 104 \\
\hline \multirow[t]{2}{*}{ Dania } & Zakres oraz wpływ podatków & 124 & 129 & 130 & 130 \\
\hline & Stopa podatkowa & 30 & 24 & 27 & 29 \\
\hline \multirow[t]{2}{*}{ Francja } & Zakres oraz wpływ podatków & 99 & 92 & 108 & 126 \\
\hline & Stopa podatkowa & 115 & 116 & 125 & 128 \\
\hline \multirow[t]{2}{*}{ Irlandia } & Zakres oraz wpływ podatków & 18 & 26 & 38 & 37 \\
\hline & Stopa podatkowa & 17 & 21 & 2 & 24 \\
\hline \multirow[t]{2}{*}{ Niemcy } & Zakres oraz wpływ podatków & 105 & 106 & 90 & 80 \\
\hline & Stopa podatkowa & 89 & 90 & 84 & 100 \\
\hline \multirow[t]{2}{*}{ Polska } & Zakres oraz wpływ podatków & 128 & 110 & 107 & 107 \\
\hline & Stopa podatkowa & 50 & 62 & 74 & 82 \\
\hline \multirow[t]{2}{*}{ Słowacja } & Zakres oraz wpływ podatków & 17 & 18 & 27 & 49 \\
\hline & Stopa podatkowa & 87 & 81 & 97 & 103 \\
\hline \multirow[t]{2}{*}{ Szwecja } & Zakres oraz wpływ podatków & 126 & 111 & 110 & 113 \\
\hline & Stopa podatkowa & 103 & 99 & 108 & 115 \\
\hline \multirow[t]{2}{*}{ Węgry } & Zakres oraz wpływ podatków & 133 & 132 & 138 & 131 \\
\hline & Stopa podatkowa & 105 & 104 & 115 & 114 \\
\hline \multirow{2}{*}{$\begin{array}{l}\text { Wielka } \\
\text { Brytania }\end{array}$} & Zakres oraz wpływ podatków & 81 & 84 & 95 & 94 \\
\hline & Stopa podatkowa & 38 & 47 & 54 & 61 \\
\hline
\end{tabular}

Źródło: Global Competitiveness Report.

Pod względem stopy podatkowej wszystkie cztery kraje oceniane sa relatywnie nisko, mimo znaczącej redukcji stawek podatków dochodowych. Wśród analizowanych krajów relatywnie najwyżej oceniana jest Polska, która w raporcie 2008-2009 znalazła się na 50 miejscu (tabela 7). Wyżej od Polski oceniane są Irlandia, Wielka Brytania i Dania.

Global Competitiveness Report zawiera także informację o tym, jak system podatkowy postrzegany jest przez przedsiębiorców prowadzących działalność gospodarczą w danym kraju. Dane opracowane są na podstawie ankiet przeprowadzanych wśród osób zarządzających przedsiębiorstwami. Respondenci 
spośród 15 czynników utrudniających prowadzenie działalności gospodarczej wybierają 5 najbardziej uciążliwych i nadają im wagi od 1 (czynnik najbardziej problematyczny) do 5. Klasyfikacja 15 najbardziej problematycznych czynników dla prowadzenia działalności gospodarczej tworzona jest na podstawie częstości, $\mathrm{z}$ jaką dany czynnik był wymieniany przez respondentów (z uwzględnieniem wag przypisanych każdemu z czynników). Im wyższa pozycja w rankingu, tym czynnik uważany jest za bardziej problematyczny.

Przepisy podatkowe były najczęściej wskazywane jako główny czynnik utrudniajaccy prowadzenie działalności gospodarczej przez przedsiębiorców z Polski i Węgier (poz. 1). Na Słowacji i w Czechach czynnik ten był wskazywany znacznie rzadziej (odpowiednio poz. 7 i 8 - tabela 8).

\section{Tabela 8}

Przepisy podatkowe jako czynnik utrudniający prowadzenie działalności gospodarczej

\begin{tabular}{|l|c|c|c|c|}
\hline & $\mathbf{2 0 0 7 - 2 0 0 8}$ & $\mathbf{2 0 0 8 - 2 0 0 9}$ & $\mathbf{2 0 0 9 - 2 0 1 0}$ & $\mathbf{2 0 1 0 - 2 0 1 1}$ \\
\hline Czechy & 7 & 9 & 8 & 3 \\
\hline Polska & 1 & 1 & 1 & 1 \\
\hline Słowacja & 7 & 7 & 7 & 7 \\
\hline Węgry & 1 & 1 & 2 & 2 \\
\hline
\end{tabular}

Źródło: Global Competitiveness Report.

Respondenci węgierscy bardzo często wskazywali także stawki podatków jako istotny czynnik utrudniający prowadzenie działalności gospodarczej. W pozostałych krajach czynnik ten wymieniany był na dalszych miejscach (tabela 9).

\section{Tabela 9}

Stawki podatków jako czynnik utrudniający prowadzenie działalności gospodarczej

\begin{tabular}{|l|c|c|c|c|}
\hline & $\mathbf{2 0 0 7 - 2 0 0 8}$ & $\mathbf{2 0 0 8 - 2 0 0 9}$ & $\mathbf{2 0 0 9 - 2 0 1 0}$ & $\mathbf{2 0 1 0 - 2 0 1 1}$ \\
\hline Czechy & 3 & 5 & 5 & 7 \\
\hline Polska & 7 & 6 & 5 & 4 \\
\hline Słowacja & 9 & 8 & 9 & 3 \\
\hline Węgry & 2 & 3 & 1 & 3 \\
\hline
\end{tabular}

Źródło: Global Competitiveness Report.

W wypadku Polski głównym czynnikiem utrudniającym prowadzenie działalności nie jest więc wysokość stawek podatków, ale skomplikowane przepisy. Węgrzy oba te czynniki uważają za istotne utrudnienie. Przedsiębiorcy z Czech i Słowacji kwestie podatkowe wymieniaja natomiast na dalszych miejscach. Reformy podatkowe okazały się więc najbardziej udane na Słowacji i w Czechach. 


\section{PODSUMOWANIE}

Analiza zmian w zakresie podatków, jakie nastąpiły w latach 2000-2011 w Czechach, Polsce, Słowacji i na Węgrzech, pozwala wyróżnić trzy główne czynniki, które były źródłem tych zmian: dostosowanie prawa podatkowego do wymagań Unii Europejskiej, działania prowadzące do poprawy i umocnienia pozycji konkurencyjnej względem krajów członkowskich UE oraz zmiany, jakie nastąpiły w reakcji na kryzys gospodarczy. Największe zmiany spowodowane reakcją na kryzys gospodarczy nastąpiły na Węgrzech, które najsilniej zostały dotknięte skutkami recesji. Polityka podatkowa Węgier, szczególnie przez inwestorów zagranicznych, postrzegana była jako chaotyczna i nieprzewidywalna, stawki podatków początkowo redukowane, były następnie podnoszone, wprowadzano dodatkowe podatki.

Reformy podatkowe mające na celu poprawę pozycji konkurencyjnej okazały się najbardziej udane na Słowacji i w Czechach. Kraje te są oceniane relatywnie wysoko z punktu widzenia wpływu podatków na konkurencyjność, a przedsiębiorcy czescy i słowaccy rzadko wskazuja przepisy i stawki podatków jako czynnik istotnie utrudniający prowadzenie działalności gospodarczej.

$\mathrm{Z}$ kolei w Polsce redukcja stawek nie w pełni przełożyła się na wzrost konkurencyjności kraju dla inwestorów. Przepisy podatkowe są nadal postrzegane jako skomplikowane i wymieniane jako jeden $\mathrm{z}$ głównych czynników utrudniających prowadzenie działalności gospodarczej. Zgodnie ze strategia podatkową Ministerstwa Finansów system podatkowy musi być reformowany w taki sposób, aby zachęcać do inwestowania, innowacji i tworzenia miejsc pracy. Temu celowi, obok obniżania nominalnych stawek podatków, ma służyć przede wszystkim wzrost pewności interpretacji prawa podatkowego.

mgr Elżbieta Gradowska

Uniwersytet Ekonomiczny w Poznaniu

TAX POLICY VIS-À-VIS THE COMPETITIVENESS OF ECONOMIES OF POLAND, THE CZECH REPUBLIC, SLOVAKIA AND HUNGARY BETWEEN 2000 AND 2011

\section{Summary}

The purpose of this paper is to compare and evaluate solutions in the field of taxation introduced in the period 2000-2011 in Poland, the Czech Republic, Slovakia and Hungary. The aim is also to determine which factors triggered tax reforms. The paper provides a comparison of changes in direct and indirect taxes and discusses the structure of tax revenues in the analysed countries. The last section discusses the impact of tax reforms on the competitiveness of economies. 
Copyright of Journal of Law, Economics and Sociology is the property of Faculty of Law and Administration of Adam Mickiewicz University in Poznan and its content may not be copied or emailed to multiple sites or posted to a listserv without the copyright holder's express written permission. However, users may print, download, or email articles for individual use.

Właścicielem praw autorskich do „Ruchu Prawniczego, Ekonomicznego i Socjologicznego” jest Wydział Prawa i Administracji Uniwersytetu im. Adama Mickiewicza w Poznaniu. Zawartość czasopisma nie może być kopiowana, przesyłana do innych stron internetowych bądź zamieszczana na blogach bez pisemnej zgody wydawcy. Niemniej artykuły można drukować, kopiować lub przesyłać w formie elektronicznej na własny użytek. 